\title{
Analysis of the Relationship Between International Service Trade and Economic Growth Based on VAR Model
}

\author{
Shuai Yang \\ \{yangshuai@126.com\} \\ International Trade and Finance Department of Zhuhai College of Jilin University \\ Guangdong Zhuhai 519041,China
}

\begin{abstract}
The rapid development of international trade in services and the focus of international trade competition from goods trade to service trade, international trade in services has become a new engine of economic growth, and gradually become an important aspect of international trade competition. The VAR model analysis of international service trade and economic growth correlation, between the two have a long and stable relationship, improve international service trade openness and international competitiveness of trade in services on economic growth plays a promoting role.
\end{abstract}

Keywords: International trade in services; economic growth; VAR model

\section{Introduction}

Since 1990s, with the continuous progress of economic globalization and China's reform and opening up, China's international trade in services has been rapid development [1].

\section{Ease of Use}

According to the statistics of WTO database, the total trade volume of China's international trade in services 1990 rose to $\$ 15.7 \%$ in 2010 , an average annual growth rate of, the growth rate has exceeded the trade in goods [2]. At the same time, in 2010 China's international trade in services exports increased to 13205 yuan, an average annual growth of $13.3 \%$; 2010China's international trade in services imports increased to 13944 yuan, an average annual growth of $19 \%$ [3]. During this period, China's international service trade openness, competitiveness, showing a rising trend, the international service trade deficit gradually narrowed, China's GDP also by 30246Billion yuan to 401202 yuan, an increase of 13.3 times [4]. Visible, the international trade in services has become new engine of economic growth in our country, and has gradually become an important aspect of international trade competition, the contribution to national economic growth will not be underestimated. Liu Dingyou and Cheng Huan (2012) believe that in the post financial crisis era, the focus of the global economic competition is shifting from trade in goods to services trade [5]. 


\section{Data sources and processing}

This paper selects the sample period is from 1990 to 2010, a total of 21 years, which in 1997 to 2010, trade in services imports, exports and import and export volume data sources to the UNCTAD database and the database of WTO related data, from 1990 to 1996 trade in services imports, exports and import and export volume data and the sample period of gross domestic product (GDP) all take the country each year "statistical yearbook". Data was the basis for unification of the exchange rate by Yuan said and through GDP reduction index (in 1985 as the base year) to overcome the price level wave drive belt to the impact. The level of international trade in services (STC), the international service trade openness (STI) is the use of the above data and calculated in accordance with the relevant formula. In the analysis process, in order to ensure the linear form of the model for analysis and avoid the phenomenon of heteroscedasticity, all variables except STC logarithm.

The variable stationary testStandard methods for the examination of smooth sequence of unit root test. In this paper, using Eviews5.1 statistical software and unit root test method most commonly used by the ADF test, unit root test for each variable Check.

Cointegration testUnit root tests had shown that LOGGDP, LOGSTI, STC three variables for a single whole sequence, and cointegration test. Before the cointegration test, according to LR, AIC and SC standards to determine the optimal lag model of VAR 2, VAR (2). Because the Johansen cointegration test is a test based on VAR regression coefficient method is a good method for multivariate co integration test, so this paper uses Trace test Johansen cointegration test.

Granger causality testWhether there is significant Granger causal relationship between the economic growth and the test of international service trade openness, international service trade competitiveness. LOGSTI, STC, LOGSTI and STC at the same timeGranger LOGGDP, the international service trade openness, international service trade competitiveness has effect on economic growth.

Impulse response analysis The Cholesky Cholesky decomposition method. Through orthogonal error of impulse response function to analyze the dynamic relationship between economic growth and international service trade opening degree, international service trade competitiveness between the level. Increasing openness of international trade in services and enhancing the competitiveness of international trade in services will have a positive impact on economic growth, while at the same time to achieve a maximum value of third, and then in the fifth period is stable. This shows that the international service trade openness increases and international service trade competitiveness enhancement in the short term the rapid economic growth, and after a certain period to maintain stable economic growth, and take various measures to improve the international service trade openness and the international trade in services competitive level for the expansion of international trade in services and spur economic growth has a positive role.

Variance decomposition in this paper, the variance decomposition of VAR model is made. Variance decomposition is through the analysis of each structural shock of students variable contribution degree, further evaluation of the importance of the impact of different structures, and the variance decomposition can be seen international services trade openness, international service trade competitiveness level of economic growth with the. China's GDP in the first period of time only by its volatility, international service trade openness, international service trade competitiveness level of economic growth in the second period is presented, impact strength is relatively small, were only $16.89 \%$ and $1.14 \%$. Since then international service trade opening, the rapid rise in the degree of impact strength, and in the 10th period 
reached maximum variance decomposition value 58.24\%. At the same time, international service trade competitiveness of the impact of rising slowly, in the 10th period reached maximum variance decomposition value of $7.95 \%$, the influence of both respectively in No. 5 and No. 7 tends to be stable. It is worth noting that the openness of the international service trade to economic growth in the contribution of fifth over the economic growth of its own contribution. Thus it can be seen, in the short term, economic growth of its larger role; however, from a long-term point of view, improve the international service trade opening degree to make the play even more than economic growth to its positive role. At the same time, we should see the level of competitiveness of international service trade on economic growth with smaller.

\section{Conclusions and Policy Recommendations}

To sum up, this paper selected from 1990 to 2010 China International Service Trade Import and export related data as well as the domestic GDP data, and with the help of related formulas were used to calculate the international service trade openness, international service trade competitiveness, the establishment of the vector self regression model (VAR) and the corresponding measurement methods, from the perspective of empirical analysis the relationship of international service trade openness, the level of competitiveness of international service trade and economic growth, we can draw the following conclusions:

1) The international service trade openness (STI), international service trade competitiveness (STC) and economic growth (GDP) between a long-term stable relationship; in the VAR model, also prove the VAR model is stationary and the variables and lagged mutual influence relationship between variables.

2) Through the Granger causality test we found that LOGSTI, STC and LOGSTI and STC can also is the Granger cause of LOGGDP, international service trade openness, international service trade competitiveness level of economic growth affect. However, Granger LOGGDP, STC are not LOGSTI, economic growth, the level of competitiveness of international trade in services are not international service trade openness impact. LOGGDP and LOGGDP and LOGSTI and STC Granger cause, that is, economic growth will have an impact on the international competitiveness of service trade and economic growth and international service trade openness can be a common impact on the international competitiveness of trade in services.

3) We further found that the impulse response analysis, The first international service trade openness increases and international service trade competitiveness enhancement in the short term makes economic fast growth, and after a certain period of time can keep the stable economic growth, and take various measures to improve the international service trade openness and international service trade competitive level for the expansion of international trade in services and spur economic growth has a positive role.

Second, economic growth and international competitiveness of trade in service enhancement has little effect on the increase in international service trade openness. That is to say, the improvement of international service trade liberalization is not is the inevitable result of economic growth and international competitiveness of trade in services to enhance the.

Third, the increase in the openness of international trade in services also has a positive impact on the level of international service trade competitiveness, especially in the short term, and then gradually decreases and tends to be stable. So as to show that in the short term, the 
economic growth and the opening degree of international trade in services have positive effects on enhancing the competitiveness of international trade in services.

4) Through the decomposition of variance to further illustrate, First, in the short term, economic growth has a greater role in promoting its own. However, from a long-term point of view, improve international service trade opening degree to make the play even more than economic growth to its positive role, and enhance the international competitiveness of trade in services is to promote effective means of economic growth. Second, the current economic growth and international trade in services to improve the competitiveness of international trade in services to promote the role of openness, so that the inhibition of the liberalization of trade in services.

Third, due to economic growth and international service trade openness is important factors of international service trade competitiveness, in economic growth while improving international service trade opening degree, China's international service trade competitive advantage will be able to give full play. Therefore, in the global international service trade rapid development and the focus of competition from trade in goods to change the service trade under the new situation, the government should put effort to improve international service trade openness and the level of competitiveness as the top priority of the development of international trade in services. It is suggested that the government: first, continue to gradually open the service sector, the introduction of advanced technology and management philosophy, continuous innovation, improve our services in the field of the overall quality of service. Second, in the service trade opening at the same time, the introduction of appropriate competition mechanism, promote China's tourism, such as building is to further realize the specialization and scale economic benefit comparative advantage of the service sector. Third, increase the knowledge intensive and technology intensive investment service industry, adjust and optimize the structure of trade in services. Finally, take the "going out" strategy, and actively expand the international service trade, to reverse the unfavorable situation of international service trade in China long-term deficit, promote the sustained and stable economic growth.

\section{Conclusion}

This paper uses the VAR model to analyze the relationship between international service trade and economic growth, there is a long-term stable relationship between the two was found. Suggest that the Chinese government should take efforts to improve the international service trade openness and the level of competitiveness as the top priority of the development of international trade in services and tried to turn the international services trade deficit situation, promote a sustained and stable economic growth.

\section{References}

[1] CuiY J, Shen F Y. "Relationship of international tradein financial services and economic growth:the case ofChina". Asian Social Science. Vol. 7, No. 9, pp. 220-225. (2011)

[2] Francois Joseph \& Kenneth Reinert, "The Role of Services in the Structure of Production and Trade: Stylized facts from Cross-Country Analysis". Asia Pacific Economic Review. No. 2, pp. 35-43. (1996)

[3] Francois, J 81 Schuknecht, L. "International Trade in Financial Services, Competition, arid Growth Performance". Centre for International Economic Studies. 6. (2000). 
[4] GeorgeVerikios, "Global gains from Liberalizing Trade in Telecommunications and Financial Services”. Productivity Commission Staff Research Paper. No. 1683, pp. 181 -206. (2001)

[5] Ramkishen, Raj an \& Graham Bird, "Will Asian Economies Gain from Liberalizing Trade in Services”. Journal of Development Economies. pp. 1061-1079. (2002) 